\title{
Domestic dogs in a fragmented landscape in the Brazilian Atlantic Forest: abundance, habitat use and caring by owners
}

\author{
Torres, $P C .^{\mathrm{a}}$ and Prado, $P{ }^{\mathrm{b}}{ }^{\mathrm{*} *}$

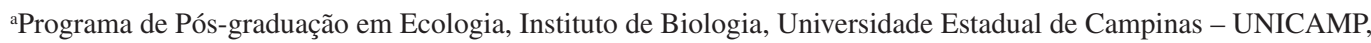 \\ Cidade Universitária Zeferino Vaz, Rua Monteiro Lobato, 255, CEP 13083-862, Campinas, SP, Brazil \\ bDepartamento de Ecologia, Instituto de Biociências, Universidade de São Paulo - USP, \\ Rua do Matão, Travessa 14, 321, Cidade Universitária, CEP 05508-090, São Paulo, SP, Brazil \\ Received August 27, 2009 - Accepted November 24, 2009 - Distributed November 30, 2010 \\ (With 2 figures)
}

\begin{abstract}
This study aimed at estimating the population size and attitudes of residents towards caring for domestic dogs, through questionnaire surveys, as well as the frequency of these animals in different habitats (anthropic and forest patch), using scent stations. The study was conducted in a severely fragmented area of the Brazilian Atlantic Forest. A large number of unrestricted dogs was recorded, averaging $6.2 \mathrm{ind} / \mathrm{km}^{2}$. These dogs have owners and are regularly fed. Dog records decreased from the anthropogenic matrix to the forest patch edge, which suggests that dogs act as an edge effect on forest patches. Encounters between domestic dog and wild animals can still be frequent in severely fragmented landscapes, mainly at the forest edges. However the fact that most dogs have an owner and are more frequent in the anthropic habitat suggests that their putative effects are less severe than expected for a carnivore of such abundance, but the reinforcement of responsible ownership is needed to further ameliorate such effects.
\end{abstract}

Keywords: Canis lupus familiaris, population size, fragmentation, edge effect, dog ownership.

\section{Cães domésticos em uma paisagem fragmentada na Mata Atlântica: abundância, uso de habitat e manejo pela população humana}

\begin{abstract}
Resumo
Este estudo tem como objetivo estimar o tamanho populacional de cães e o manejo dado a eles pela população humana através de questionários, bem como estimar a frequência de ocorrência desses animais em diferentes hábitats (antrópico e fragmento florestal), usando armadilhas de pegadas. $\mathrm{O}$ estudo foi realizado em uma área altamente fragmentada de Mata Atlântica no Estado de São Paulo. Encontramos um grande número de cães soltos, uma média de 6.2 ind $/ \mathrm{km}^{2}$. Esses animais possuem donos e são constantemente alimentados. $\mathrm{O}$ número de registros de cães diminui da matriz antrópica para o interior dos fragmentos florestais, o que sugere que cães podem atuar como um efeito de borda sobre os fragmentos. Ainda assim, encontros entre cães domésticos e animais silvestres podem ser frequentes em paisagens intensamente fragmentadas, principalmente nas bordas dos fragmentos. No entanto, o fato de que os cães são mais frequentes no ambiente antrópico e a maioria tem dono, sugere que o impacto causado por eles no ambiente natural é menos severo que o esperado para um carnívoro em tal abundância, mas a exigência de responsabilidade por parte dos donos pode reduzir ainda mais este impacto.
\end{abstract}

Palavras-chave: Canis lupus familiaris, tamanho populacional, fragmentação, efeito de borda.

\section{Introduction}

In megadiverse areas like Africa and Latin America, domestic dogs (Canis lupus familiaris Linnaeus) pose serious risks to native species as vectors of diseases, predators and competitors (Butler and Bingham, 2000; Butler and du Toit, 2002; Fiorello et al., 2006; Galetti and Sazima, 2006; Oliveira et al., 2008; Whiteman et al., 2007). Such threats are more important in rural and periurban areas of tropical regions, where households typically own dogs that are allowed to roam and breed freely (Butler and Bingham, 2000; Butler and du Toit, 2002; Kitala et al.,
2001; Fiorello et al., 2006). This is seemingly the case in Brazil, but only five studies have been published to date on actual or potential impacts of domestic dogs on wildlife, in very different contexts (Campos et al., 2007; Galetti and Sazima, 2006; Lacerda et al., 2009; Srbek-Araujo and Chiarello, 2008; Whiteman et al., 2007). Few other works reported domestic dogs in areas of conservation interest in Brazil (Monteiro-Fillho, 1995; Srbek-Araujo and Chiarello, 2005) and speculated about the impacts caused by these animals on protected areas. 
These studies point out that the presence of dogs is an important risk factor to the native fauna, mainly due to their potential to chase and hunt wild animals, as reported by some authors in the Brazilian savanna (MarinhoFilho et al., 1998). According to Lacerda et al. (2009) the maned wolf (Chrysocyon brachyurus Illiger) and the giant anteater (Myrmecophaga tridactyla Linnaeus) seem to avoid areas with dog tracks. In a fragmented landscape in the Amazon, the presence of domestic dogs is related to disease transmission for wild carnivores (Whiteman et al., 2007). In the Brazilian Atlantic Forest, dogs have also been reported to threaten wildlife. Galetti and Sazima (2006) concluded that predation by feral dogs is the major cause of extinction of many species in a protected Atlantic Forest remnant, and that edge dwellers are particularly more vulnerable.

Two of the studies mentioned were carried out in protected areas, in the Atlantic forest, close to cultural landscapes, such as urban centres (Galetti and Sazima, 2006; Srbek-Araujo and Chiarello, 2008), but they did not address the relationship between the surrounding human population and the occurrence of dogs inside those forest patches, as we proposed to do in our study. The presence of unrestricted domestic dogs, those allowed to roam free the entire day or part of it is a result of human attitudes towards their pets, and is extremely common in Brazilian rural and periurban landscapes. These landscapes have been severely disturbed by human activities and in areas where native forest still remains, they are split in small patches, surrounded by a matrix (the dominant background) of pasture, agricultural fields or settlements. However, even basic information is surprisingly scarce and there is no known estimate of owned to stray dog ratio, and what kind of attitudes towards caring for these animals the owners have.
Therefore, this work presents basic data about abundance, caring and behaviour of domestic dogs in a fragmented landscape in the Brazilian Atlantic Forest, which can be used to evaluate and mitigate the impacts of this exotic species in this Biodiversity Hotspot. The specific questions that we addressed were: 1) what is the dog population size in two rural areas? 2) What are the residents' attitudes towards caring for their dogs? 3) How frequently do dogs use the landscape matrix, forest edge and forest patches?

\section{Methods}

\subsection{Study area}

The study areas were located in the northern portion of the municipality of São Luiz do Paraitinga, São Paulo State, Brazil (centreed in $23^{\circ} 20^{\prime} \mathrm{S}$ and $45^{\circ} 20^{\prime} \mathrm{W}$ ). Forest covers about $10 \%$ of the area, being split in small and disturbed patches (less than 80 ha), scattered in a matrix dominated by pastures. Many pasture areas are being replaced by monospecific plantations of the exotic tree Eucalyptus sp. The southern region of the municipality includes a part of a large remnant of Atlantic Forest (about 315,000 ha) in the Serra do Mar mountain range, which is protected as the Serra do Mar State Park. The survey was carried out in two rural regions: one is occupied by small and medium-sized dairy and vegetable farms and the other by large Eucalyptus farms, mostly for paper and wood pulp mills, representing the two most common landscape matrices in the municipality.

\subsection{Study areas selection}

In each region a forest patch of secondary forest of at least 40 years old and larger than 10 ha was randomly selected, from which a $2 \mathrm{~km}$-wide buffer was set out (Figure 1). A second patch with the same characteristics was then picked at random in each buffer area. The survey

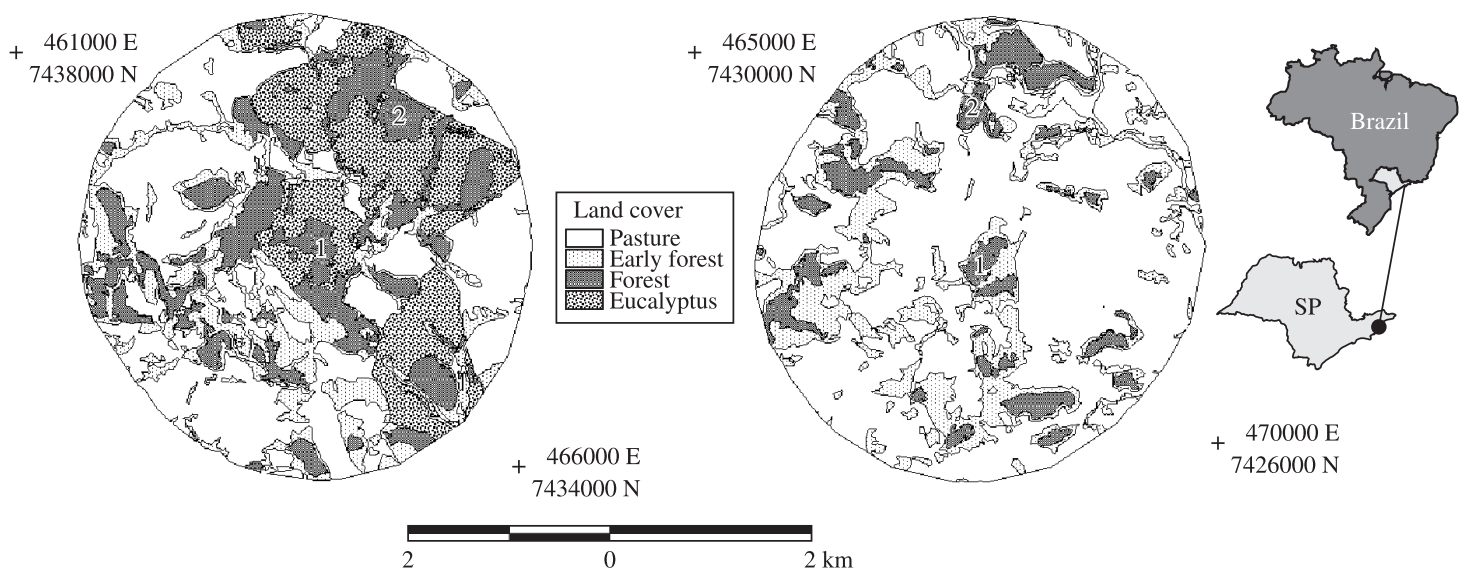

Figure 1. Land cover of the two study areas (Eucalyptus and Pasture Areas). The areas were $2 \mathrm{~km}$-wide buffers around two forest patches larger than 10 ha randomly chosen from the two distinct landscapes that characterise most of the area of the municipality of São Luiz do Paraitinga. In each area the forest patch used to outline the buffer and an additional one were surveyed. These patches are indicated by the numbers one and two, respectively, and are named E1 and E2 (Eucalyptus area) and P1 and P2 (Pasture area) (see Methods for details). 
comprehended the areas delimited by these buffers, which will be referred hereafter as Eucalyptus Area and Pasture Area. The surveyed forest patches in the Eucalyptus have areas of 15.8 ha and 53.8 ha and perimeters of 4,072 $\mathrm{m}$ and $16,902 \mathrm{~m}$, respectively. For the patches in the Pasture area the areas were 17.4 ha and 17.9 ha and perimeters were $6,374 \mathrm{~m}$ and 8,940 $\mathrm{m}$. The land cover in the Pasture Area was $66 \%$ of pasture, $24 \%$ early secondary forest, $10 \%$ secondary forest. In the Eucalyptus Area the figures are $38 \%$ of pasture, $22 \%$ of Eucalyptus plantations, $18 \%$ of early secondary forest, and $21 \%$ of secondary forest. Cover classes were obtained from a supervised classification of a SPOT satellite image, $5 \times 5$ pixel (October 2002, minimum accuracy of the land cover classification: $85 \%$ ).

\subsection{Dog population size}

The number of dogs whose owners live in the study areas (Eucalyptus Area and Pastures Area defined above) was obtained by visiting all occupied houses in each area and interviewing their householders (68 and 51 houses in the first survey and 71 and 55 in the second survey in the Eucalyptus Area and Pasture Area, respectively). To check the presence of dogs whose owners do not live in the area a total of $42 \mathrm{~km}$ of dirt roads were walked in each area (21 km back and forth), which represents half of the total road length in the areas, and all dogs sighted were photographed for identification by the local residents. As only two dogs not recognised as having an owner were found in one area in only one of the surveys, and as every occupied house in each area was surveyed for owned dogs through interviews, the total number of dogs in each area was obtained as the sum of the individuals recorded with these two survey methods, and no estimation procedure was applied.

Both surveys were repeated twice in each area. The first period of interviews took place in September and November 2004 and the second in October 2005. For the first road searching, the roads were walked during two consecutive mornings from 6:30 AM to 10 AM in January 2005 in the Pasture Area and in March 2005 in the Eucalyptus Area. For the second time, the roads were walked during two consecutive mornings in October 2005, from 6:30 AM to $10 \mathrm{AM}$, in both areas.

\subsection{Residents' attitudes towards caring for their dogs}

The characterisation of the residents' attitudes towards caring for their dogs was done through questionnaire surveys conducted with each householder of the study areas (for total number of houses, see item above). The data collected were the number of dogs in each household, how they were kept by their owners (unrestricted - those allowed to roam free the entire day or part of it, or confined), if the owners had any information about their dogs habits outside home (home range, feeding and hunting), if the animal has ever brought home any wild animal and the frequency with which they feed their dogs. The residents' answers were analysed separately for each area.

\subsection{Habitat use}

In order to quantify the frequency of use of different habitat types by the dogs in both study areas, scent stations were installed inside and around the two forest patches chosen in each area, to record animal footprints (Pardini et al., 2003). The surveyed habitats were defined as 1) forest: the core of the forest patch, which was the interior area within a minimum distance of $20 \mathrm{~m}$ from the patch boundary to the surrounding pasture or Eucalyptus matrix; 2) edge: a $4 \mathrm{~m}$ wide border of the forest patch; and 3) matrix: the surrounding pasture or Eucalyptus areas, at a minimum distance of $30 \mathrm{~m}$ and maximum distance of $150 \mathrm{~m}$ from the patch boundary. Seven stations were set at each habitat type of each patch and its surroundings. The forest stations were set in three random points inside the forest patch and on the trails between these points. On the edge the stations were distributed regularly along the patch perimeter. In the landscape matrix, the stations were all set at random. The set of 21 stations in and around each forest patch will be referred to hereafter as "blocks", and will be denominated P1 and P2 (in the Pasture Area) and E1 and E2 (in the Eucalyptus Area).

The scent stations in each block were set up with a minimum distance of $50 \mathrm{~m}$ between them. Each station consisted of a squared sand bed of $70 \times 70 \mathrm{~cm}$ and about $2 \mathrm{~cm}$ deep, lined with fine sieved sand. Stations were baited with liquid carnivore scent lures (Russ Carman's Pro-Choice and Canine Call, Sterling Fur and Tool, Sterling, Ohio). Three drops of each lure were dropped every two days (Crooks, 2002). Footprints were identified according to the Becker and Dalponte guide (1991). The presence of footprints in a station in each inspection day was considered a record, regardless of the number of footprints and individuals that might have left them. Scent station data were collected in mid-and late-2005 and early-2006 and data for all patches were collected in each field campaign, with the same sample effort for all patches, accounting for a total of 33 field days. Each station was inspected 9 or 10 times, a variation due to station damage caused by rain and cattle.

\subsection{Statistical analysis}

Confidence intervals were estimated for the mean number of dogs per house by the percentile bootstrap method (Manly, 1997), for each study area and census.

A permutation procedure was used to test the differences among habitats and among forest patches in the number of records of dogs and wild animals in the scent stations. These differences were gauged by the odds-ratios of getting a record (Equation 1):

$\mathrm{O}_{\mathrm{ij}}=\frac{\mathrm{n}_{\mathrm{i}} / \mathrm{N}_{\mathrm{i}}}{\mathrm{n}_{\mathrm{j}} / \mathrm{N}_{\mathrm{j}}}$

where $\mathrm{O}_{\mathrm{ij}}$ is the estimated odds-ratio of a record among habitats (or patches) $\mathrm{i}$ and $\mathrm{j}, \mathrm{n}$ is the number of records, and $\mathrm{N}$ is the total number of inspections, in each habitat or patch.

Under the null hypothesis of no differences, the odds-ratio is one. This hypothesis could not be tested with standard 
procedures, because our records were not independent observations. They came from repeated inspections of the same scent stations in each habitat, and the stations laid in the three habitats were set in four blocks - the four forest patches and their surroundings. Hence, to test differences among habitats, the stations were randomly shuffled between habitats within each patch and then the odds-ratio of recording a dog was calculated for each pair of habitats. The procedure was repeated 10,000 times, and the significance of the observed odds-ratio was estimated as the proportion of permutations that had an equal or higher value of the statistic. To test differences among blocks, stations were shuffled between them, but within the same habitat. All analyses were done with the 'boot' package (Canty and Ripley, 2005), in the R environment version 2.4.0 for LINUX (R Development Core Team, 2006).

\section{Results}

\subsection{Dog population size}

According to the interviews the total number of owned dogs ranged between 92 and 102 in each study area and the proportion of restricted animals never reached $25 \%$ (Table 1). These numbers differed only slightly between areas or surveys (Table 1). Thus, the density of dogs that were not restricted by their owners ranged between $5.7 \mathrm{ind} / \mathrm{km}^{2}$ (Eucalyptus Area, $1^{\text {st }}$ survey) and $6.9 \mathrm{ind} / \mathrm{km}^{2}$ (Pasture Area, $1^{\text {st }}$ survey, Table 1). Mean dogs per household ranged from 1.35 to 2.00 and mean dogs per dog-owning household ranged from 1.96 to 2.90 .

Only houses that were permanently inhabited (44 in the Eucalyptus Area in the $1^{\text {st }}$ census and 43 in the $2^{\text {nd }}$ and 36 in the Pasture Area in the $1^{\text {st }}$ census and 30 in the $2^{\text {nd }}$ ) owned dogs. Only three of those houses did not own dogs in the Eucalyptus Area (6.8\%) in the first census and five $(11.6 \%)$ in the second census. In the Pasture Area only one household did not own dogs in both censuses $(2.8 \%$ and $3.3 \%$ in the $1^{\text {st }}$ and $2^{\text {nd }}$ census, respectively). If our estimates are representative of the entire rural area of São Luiz do Paraitinga, where in 2000 there were 1,265 households (IBGE, 2000), the total number of owned dogs would range between 1,316 and 3,225 animals. As the rural zone area is $1,538 \mathrm{~km}^{2}$, the estimated population density for the entire municipality is between 0.86 and $2.09 \mathrm{ind} / \mathrm{km}^{2}$, a much smaller number than that obtained for the two study areas, where house density is higher than that of the southern part of the municipality.

\subsection{Residents' attitudes towards caring for their dogs}

According to the dog owners, the Pasture Area presented a higher number of animals that leave the property without their owners, 59 against 29 from the Eucalyptus Area (Table 2). However, the numbers of unrestricted dogs in both areas and surveys are similar, ranging from 70 to 80 in the Pasture Area and 76 to 87 in the Eucalyptus Area (Table 1), as well as the numbers of animals that feed while out of their household (24 in the Pasture Area and 23 in the Eucalyptus Area) and that already brought a wild animal home (9 in the Pasture Area and 12 in the Eucalyptus Area) (Table 2). Two of the owners reported that they have seen their dogs chasing wild animals (total of four dogs, three in the Eucalyptus Area and one in the Pasture Area). All owners said they feed their dogs at least twice daily and dogs did not have obvious signals of malnutrition.

Table 1. Numbers of dogs with owners in each area and survey: total, unrestricted and mean dogs per house (bootstrap 95\% confidence intervals in parentheses).

\begin{tabular}{lccccc}
\hline & \multicolumn{2}{c}{$\mathbf{1}^{\text {st }}$ survey } & & \multicolumn{2}{c}{$\mathbf{2}^{\text {nd }}$ survey } \\
\cline { 2 - 3 } \cline { 5 - 6 } & Eucalyptus & Pasture & & Eucalyptus & Pasture \\
\hline Total & 92 & 102 & & 100 & 93 \\
Unrestricted & 70 & 87 & 80 & 76 \\
Mean dogs/household & $1.35(1.04-1.69)$ & $2.00(1.49-1.73)$ & & $1.41(1.09-1.73)$ & $1.69(1.20-2.24)$ \\
$\begin{array}{l}\text { (95\% C.I.) } \\
\text { Mean dogs/dog-owning }\end{array}$ & $1.96(1.64-2.32)$ & $2.54(2.10-3.10)$ & & $2.10(1.75-2.43)$ & $2.90(2.40-3.50)$ \\
household (95\% C.I.) & & & & \\
\hline
\end{tabular}

Table 2. Unrestricted dogs' behaviour in both areas.

\begin{tabular}{lcccc}
\hline & \multicolumn{2}{c}{ Eucalyptus } & & \multicolumn{2}{c}{ Pasture } \\
\cline { 2 - 5 } \cline { 4 - 5 } & $\mathbf{N}$ & $\mathbf{\%}$ & $\mathbf{N}$ & $\mathbf{\%}$ \\
\hline Leave property - unsupervised & 29.0 & 41.2 & 59.0 & 67.8 \\
Eat out of the household & 23.0 & 32.3 & 24.0 & 27.6 \\
Brought animal back home & 12.0 & $17.6^{\mathrm{a}}$ & 9.0 & $10.3^{\mathrm{b}}$ \\
\hline
\end{tabular}

${ }^{a}$ porcupine (Coendou sp. or Sphiggurus sp.), wildcat (Leopardus sp.), opossum (Didelphis sp.), armadillo or snake (not identified to species or genera level). ' agouti (Dasyprocta sp.), porcupine (Coendou sp. or Sphiggurus sp.), opossum (Didelphis sp.), or snake (not identified to species or genera level). 


\subsection{Habitat use}

The total number of station inspections was 845 in the three habitats and four blocks, from which we obtained 43 records of dogs and 159 records of animals known to be native. The opossum (Didelphis sp.) and the domestic dog were the most recorded species (Table 3 ).

Dog records were more frequent in the matrix than in the forest interior in the Pasture Area blocks (Figure 2a). In the landscape matrix in the Pasture Area blocks there were a total of 24 records of dogs from 114 inspections of scent stations, while inside the forest patches this proportion was $7 / 119$. Thus we can estimate that the chance of recording a dog in the matrix is more than three times higher than in the forest (odds-ratio $=3.58$ ). This is far from that expected by the null hypothesis, since only 170 of the 10,000 randomisations resulted in an odds-ratio equal or greater than that $(\mathrm{p}=0.017)$. The odds-ratio between forest and forest edge was 2.64 , which is nearly significant $(p=0.06)$. On the other hand, the ratio between the two blocks in the pasture area (forest, edge and matrix pooled together) was close to one (odds-ratio $=1.07, \mathrm{p}=0.46$ ). In the Eucalyptus Area there were only three records, one in each habitat type (Figure 2a). Such a small number of records did not provide enough different permutations to allow testing among habitats or blocks in this Area.

Records of wild animals were more frequent inside the patches for all blocks but P2, which had only one record (Figure 2b). As one would expect, wild animals showed the opposite trend of dogs and had significantly higher odds to be recorded inside forest patches than on the edge and landscape matrix (ratios for pooled habitat stations: forest $\times$ matrix: odds-ratio $=2.12, \mathrm{p}<0.0001$, forest $x$ edge: odds-ratio $=1.72, p=0.005$, edge $\times$ matrix: odds-ratio $=1.24, \mathrm{p}=0.16$, Figure $2 \mathrm{~b}$ ). Also, blocks in the same area differed statistically in the odds of having records of wild animals (ratio for pooled block stations: $\mathrm{P} 1 \times \mathrm{P} 2$ : odds-ratio $=19.6, \mathrm{p}<0.0001, \mathrm{E} 1 \times \mathrm{E} 2$ : oddsratio $=2.6, p<0.0001$, Figure $2 b)$.

Table 3. Species registered on the scent stations, number of records, and number of blocks where they were registered.

\begin{tabular}{|c|c|c|}
\hline Species & $\begin{array}{c}\text { Number } \\
\text { of } \\
\text { records }\end{array}$ & $\begin{array}{c}\text { Number } \\
\text { of } \\
\text { blocks }\end{array}$ \\
\hline Canis lupus familiaris ${ }^{\mathrm{a}}$ & 43 & 4 \\
\hline Didelphis sp. & 150 & 4 \\
\hline Cerdocyon thous Linneaus & 4 & 1 \\
\hline Leopardus pardalis Linnaeus & 1 & 1 \\
\hline Hydrochaeris hydrochaeris Linnaeus & 1 & 1 \\
\hline Eira barbara Linnaeus & 1 & 1 \\
\hline Small marsupial & 2 & 2 \\
\hline Small felid ${ }^{\mathrm{b}}$ & 2 & 1 \\
\hline Small rodent ${ }^{\mathrm{c}}$ & 5 & 4 \\
\hline Lepus europaeus Pallas ${ }^{a}$ & 6 & 1 \\
\hline
\end{tabular}

axotic species; ${ }^{\mathrm{b}}$ not identified to species level, might include the domestic cat (Felis catus); and ${ }^{\mathrm{c}}$ not identified to species level, might include an exotic species.

\section{Discussion}

Even the minimum density of unrestricted domestic dogs in the studied areas $\left(5.7 \mathrm{ind} / \mathrm{km}^{2}\right)$ was high in comparison to similar wild species. The crab-eating fox (Cerdocyon thous Linnaeus), is the most generalist canid of the Neotropics (Facure and Monteiro-Filho, 1996; MottaJunior et al., 1994), but occurs at densities far lower than those reported for domestic dogs in this study. The few estimates available for $C$. thous range from $0.003 \mathrm{ind} / \mathrm{km}^{2}$ to $4 \mathrm{ind} / \mathrm{km}^{2}$ (Duran et al., 1987; Eisenberg et al., 1979; Maffei and Taber, 2003; Yanoski and Mercolli, 1990). An estimate of dingoes (Canis lupus dingo Meyer) density in Western Australia was also lower, 22.2 ind $/ 100 \mathrm{~km}^{2}$ (Thomson et al., 1992).

Nevertheless, other studies show higher density estimates of domestic dogs in rural areas. Butler and Bingham (2000) and Kitala et al. (2001) found an average density of $20.9 \mathrm{dogs} / \mathrm{km}^{2}$ and $13.5 \mathrm{dogs} / \mathrm{km}^{2}$, in rural and periurban areas, respectively, in Africa. Yet, the mean number of dogs per house in these studies (around 1.5) were similar to that reported here (1.35 to 2.00). In these studies the densities of households were on average three times higher. Owning dogs is the rule in the study areas, as almost all of the permanently inhabited houses had at least one dog. So the owners' attitudes towards their dogs constitute a very important factor that influence their behaviour, especially regarding the area they use, as many dogs are free to roam at any time. As the number of stray dogs seems to be much smaller than that of owned ones, dog density is directly
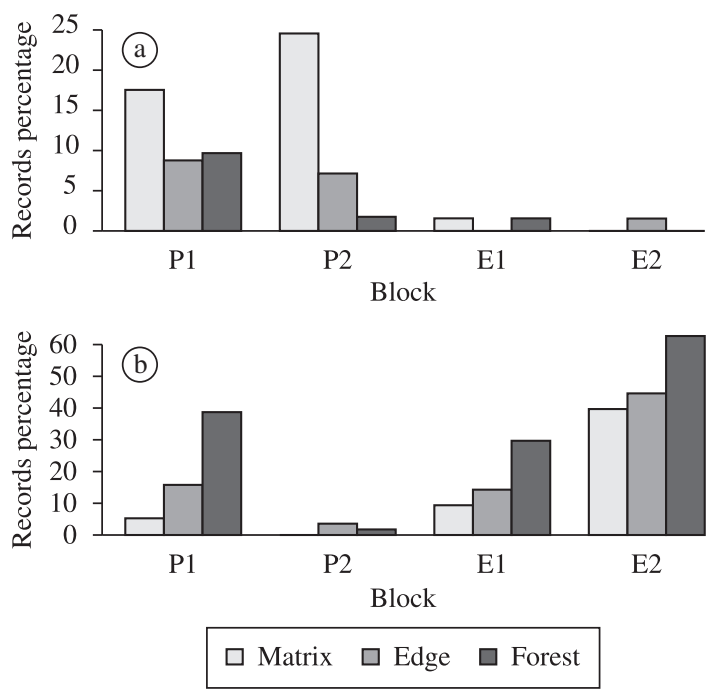

Figure 2. Percentage of records of a) domestic dog and b) wild animals from the total number of possible records in every habitat in each study area. The number of possible records is the number of inspections in which the station was not damaged by weather (rain or very dry sand due to heat). Total number of inspections per habitat in each area: P1 forest: 62, P1 edge: 57 P1 matrix: 57, P2 forest: 57, P2 edge: 58, P2 matrix: 57, E1 forest: 67, E1 edge: 65, E1 matrix: 63, E2 forest: 64, E2 edge: 63, E2 matrix: 64. 
linked to the density of houses rather than the area and the availability of food resources, as expected for wild animals. A number of studies suggest that dog densities in many areas (rural and urban) are closely linked to human densities (Brooks, 1990; Butler and Bingham, 2000; Kitala et al., 2001; Reithinger et al., 2003). Kitala et al. (2001), studying the ecology and demography of dogs in a district in Kenya, pointed out that dog densities are dependent on human densities, as all dogs observed in the study were owned and the research was carried out by interviewing the residents. Fiorello et al. (2006) also found that all dogs in their study areas (local communities in a reserve's buffer zone in the Isoso of Bolivia, an area of tropical dry forest) were owned and also that essentially all households had dogs. This is consistent with our results, since more than $90 \%$ of the households in our study areas had dogs. Yet, other studies found a lower percentage of households owning dogs in rural areas and small villages in the countryside or adjacent to reserves, varying from $48 \%$ (Gavgani et al., 2002) to $81 \%$ (Navin et al., 1985), being in most cases around $60 \%$ (Reithinger et al., 2003; Wang et al., 2005; Kitala et al., 2001).

The high density of dogs can pose a threat to wildlife through hunting. Although Lacerda (2002) did not find any evidence of wild mammals in the stomach contents of domestic dogs in an area of Brazilian savanna, Galletti and Sazima (2006) found evidence of domestic dogs hunting wild mammals in an Atlantic forest patch. Despite the small and fragmented forest cover in our study areas, potential prey is unequivocally available, as shown by the tracks left by wild species in the scent stations. Since the attractants in the scent stations were specific for carnivores, the tracks left by wild species are an underestimate for wild animals that use those patches. In a study in the Atlantic forest, Passamani and Ribeiro (2009) found that a great percentage of the small mammals' community of forest patches also use the matrix regularly, mainly as corridors between patches. Therefore, those animals can become more vulnerable to dog hunting. Hunting episodes do occur, as informed by residents, who probably witness only a small fraction of these events. In the Cerrado, hunting by domestic dogs is an important risk factor for the maned wolf (Chrysocyon brachyurus) and other terrestrial mammals in this biome (Monteiro-Filho, 1995), since dogs can form packs (Nesbitt, 1975; Daniels and Bekoff, 1989). Oliveira et al. (2008) reported predation on a primate in a protected area in the Brazilian Atlantic Forest. However, according to Butler and $\mathrm{du}$ Toit (2002) the constant supply of food can decrease the impact of domestic dogs on local wildlife. In the study area, all owned dogs (which represent almost the entire population) are regularly fed by their owners, which might decrease their impact on wildlife. But dogs can be more likely to be involved in predator-prey instinctive games than in hunting subsistence as shown for cats by Crook's and Soulé's work (1999). This can occur when animals rely on local abundant resources, provided directly or indirectly by human population, which is the case of the dogs of this study.
The records in the scent stations point a clear preference of the dogs by the pasture habitats in comparison with the adjacent forest. As expected, edge habitats had intermediate odds to be used by dogs, and did not differ statistically from none of the two other habitats. Hence, the potential effects of dogs on forest patches decreases from the anthropogenic matrix to the forest interior. In this sense, dogs can be considered as an edge effect as previously suggested by Srbek-Araujo and Chiarello (2008) for the Atlantic Forest domain and also by Lacerda et al. (2009) in the Brazilian savanna. In Australia, a survey about dingo's (Canis lupus dingo) diet showed that, in a fragmented landscape, forest edge dwellers were the most frequent preys in dingo's diet, suggesting that these animals are more frequent in this habitat (Vernes and Dennis, 2001). Revilla et al. (2001), studying edge effects on the abundance of the Eurasian badger (Meles meles Linnaeus) and those of other animals that could affect it, in the Doñana National Park, in Spain, observed that the edge had a positive effect in C. familiaris, as more tracks were found in this habitat. Dogs were included in Revilla's and colleagues' study because they may kill badgers (Neal and Cheeseman, 1996) and also for being considered a good indicator of human interference (Jenkinson and Wheater, 1998). Butler and du Toit (2002) also found dogs more frequently on the border of a wildlife reserve in Zimbabwe than in its interior.

Dog records were much more frequent in the Pasture Area compared to Eucalyptus Area. Landscape effects can be a plausible explanation for this difference, notably matrix permeability, since the owners' management practices did not differ between the two areas. If dogs prefer open habitats instead of forested ones, the studied forest patches may be buffered by the matrix of Eucalyptus that surrounds them almost completely (Figure 1). Srbek-Araujo and Chiarello (2008) found a higher number of records near a reserve's border with agriculture, where rural human residences are closer, than near the border with still a large tract of forest, which could be acting as a buffer. Moreover, studied forest patches in the Pasture Area are alongside main dirty roads and thus can be accessed much more easily than the patches in the Eucalyptus Area, where dogs may be eluded by the complex network of small and convoluted trails that cut the plantations.

Domestic dogs are part of the processes of occupation and landscape use by humans. They have become the most abundant carnivore in rural areas and in Brazil the traditional management practice is to keep them unrestricted, and thus free to roam through the matrix and enter the forest patches, as recorded for other tropical areas. Kitala et al. (2001) surveyed management practices and found that many dogs spend considerable time roaming freely, since $69 \%$ of the dogs were never restricted and only $19 \%$ of the households restricted their dog's movements at all times. Ortega-Pacheco et al. (2007) also found a high proportion of unrestricted dogs in a rural area in Mexico (77\%). In severely fragmented landscapes, as is the rule in the Atlantic Forest ecoregion (Morellato and Haddad, 2000; Viana et al., 1997), forest patches are scarce, small 
and close to houses, and thus highly vulnerable to the entrance of domestic animals from the surrounding matrix. The use of forest patches not only by dogs, but also by cattle, horses, goats, pigs, and cats, is clearly an important ecological process in fragmented landscapes, though still poorly appreciated in the Neotropics.

On the other hand, at least in our study, the fact that most dogs have an owner and that they prefer non-forested habitats may attenuate the enormous impacts expected for a generalist carnivore in such high abundance if it relied only on forest resources. Still, domestic dogs may hunt for recreation, which is a behaviour that can have great impact on wild vertebrates (Crooks and Soulé, 1999). Hence, evaluating this impact is an essential goal that still needs to be examined in the Neotropics. But even before this, three simple management practices are clearly of vital importance to avoid the impact of domestic dogs in forest fragments, namely, to convince owners to keep their dogs restricted, well fed and vaccinated. Therefore it is of vital importance to promote education in the human population about responsible ownership as we notice a strict relation between people's attitudes towards dogs and their interaction with native species.

Acknowledgements - We enormously thank R. Pardini for providing thoughtful comments throughout this work. We thank E. Vieira for important comments and F. Palomares and other two anonymous referees for reviewing the manuscript. This work was supported by the Fundação de Amparo à Pesquisa no Estado de São Paulo (Programa BIOTA/FAPESP grant 01/13341-3 and grants 04/00708-8 and 05/58801-2) and partly by the State University of Campinas.

\section{References}

BECKER, M. and DALPONTE, JC., 1991. Brazilian wild mammals' tracks: a field guide. Brasília, DF: Editora UNB, 180 p.

BROOKS, R., 1990. Survey of the dog population of Zimbabwe and its level of rabies vaccination. Veterinary Record, vol. 127, no. 24 , p. $592-596$.

BUTLER, JRA. and BIRGHAM, J. 2000. Demography and dog-human relationships of the dog population in Zimzabwean communal lands. The Veterinary Record, vol. 147, p. 442-446.

BUTLER, JRA. and DU TOIT, JT., 2002. Diet of free-ranging dogs (Canis familiaris) in rural Zimbabwe: implications for wild scavengers on the periphery of wildlife reserves. Animal Conservation, vol. 5, p. 29-37.

CAMPOS, CB., ESTEVES, CF., FERRAZ, KMPMB., CRAWSHAW, Jr., PG. and VERDADE, LM., 2007. Diet of free-ranging cats and dogs in a suburban and rural environment, south-eastern Brazil. Journal of Zoology, vol. 273, p. 14-20.

CANTY, A. and RIPLEY, B., 2005. Bootstrap R (S-Plus). Functions (Canty). R package version 1.2-23.

CROOKS, K., 2002. Relative Sensitivities of Mammalian Carnivores to Habitat Fragmentation. Conservation Biology, vol. 16, no. 2, p. 488-502.

CROOKS, KR. and SOULÉ, ME., 1999. Mesopredator release and avifauna extinctions in a fragmented system. Nature, vol. 400, no. 6744 , p. $563-566$.
DANIELS, TJ. and BEKOFF, M., 1989, Spatial and temporal resource use by feral and abandoned dogs. Ethology, vol. 81, p. 300-312.

DURAN, JC., CATTAN, PE. and YANEZ, JL., 1987. Food-habits of foxes (Canis sp.) in the Chilean National Chinchilla Reserve. Journal of Mammalogy, vol. 68, no. 1, p. 179-181.

EISENBERG, JF., O'CONNEL, MA. and AUGUST, PV., 1979. Density, productivity and distribution of mammals in two Venezuelan habitats. In EISENBERG, JF. (Ed). Vertebrate ecology in the northern Neotropics. Washington, D.C.: Smithsonian Institution Press, p. 187-207.

FACURE, KG. and MONTEIRO-FILHO, ELA., 1996. Feed habits of the crab-eating fox, Cerdocyon thous (Carnivora, Canidae), in a suburban area of southeastern Brazil. Mammalia, vol. 60 , p. 147-149.

FIORELLO, CV., NOSS, AJ. and DEEM, SL., 2006. Demography, hunting ecology, and pathogen exposure of domestic dogs in the Isoso of Bolivia. Conservation Biology, vol. 20, no. 3, p. 762-771.

GALETTI, M. and SAZIMA, I., 2006. Impact of feral dogs in an urban Atlantic Forest fragment in southeast Brazil. Natureza e Conservação, vol. 4, no. 1, p. 146-151.

GAVGANI, ASM., MOHITE, H., EDRISSIAN, GH., MOHEBALI, M. and DAVIES, CR., 2002. Domestic dog ownership in Iran is a risk factor for human infection with Leishmania infantum. American Journal of Tropical Medicine and Hygiene, vol. 67, no. 5 , p. 511-515.

IBGE, 2000. Fundação Instituto Brasileiro de Geografia e Estatística. Censo 2000. Available from: <http://www.ibge.gov.br>.

JENKINSON, S. and WHEATER, CP., 1998. The influence of public access and sett visibility on badgers (Meles meles) sett disturbance and persistence. Journal of Zoology, vol. 246, p. $478-482$.

KITALA, P., McDERMOTT, J., KYULE, M., GATHUMA, J., PERRY, B. and WANDELER, A., 2001. Dog ecology and demography information to support the planning of rabies control in Machakos District, Kenya. Acta Tropica, vol. 78, p. 217-230.

LACERDA, ACR., 2002. Análise de Ocorrência de Canis familiaris no Parque Nacional de Brasília: Influência da Matriz, Monitoramento e Controle. Brasília, DF: Universidade de Brasília. [Dissertação de Mestrado].

LACERDA, ACR., TOMAS, WM. and MARINHO-FILHO, J., 2009. Domestic dogs as an edge effect in the Brasília National Park, Brazil: interactions with native mammals. Animal Conservation, vol. 12, p. 477-487.

MAFFEI, L. and TABER, AB., 2003. Distribution, natural history and conservation of neotropical mammals. Journal of Neotropical Mammalogy, vol. 10., no. 1, p. 154-160.

MANLY, BF., 1997. Randomization, bootstrap and Monte Carlo methods in ecology. London: Chapman and Hall.

MARINHO-FILHO, JS., RODRIGUES, FHG. and GUIMARÃES, MM., 1998. Mammals from Águas Emendadas Ecological Station. In MARINHO-FILHO, JS., RODRIGUES, FHG. and GUIMARÃES, MM. (Eds.). Vertebrates of Águas Emendadas Ecological Station. Brasília, DF: SEMATEC/IEMA, p. 34-63.

MONTEIRO-FILHO, ELA., 1995. Mammals from Santa Genebra. In MORELLATO, LPC. and LEITÃO-FILHO, HF. (Eds.). 
Conservation Ecology of a urban Tropica Forest, Santa Genebra Reserve. Campinas, SP: Editora Unicamp, p. 86-92.

MORELLATO, LPC. and HADDAD, CFB., 2000. Introduction: The Brazilian Atlantic Forest. Biotropica, vol. 32, no. 4B, p. 786-792.

MOTTA-JUNIOR, JC., LOMBARDI, JA. and TALAMONI, SA., 1994. Notes on crab-eating fox (Dusicyon thous) seed dispersal and food habits in southeastern Brazil. Mammalia, vol. 58 , p. 156-159.

NAVIN, TR., SIERRA, M., CUSTODIO, R., STEURER, F., PORTER, CH. and RUEBUSH, TK., 1985. Epidemiologic study of visceral leishmaniasis in Honduras, 1975-1983. American Journal of Tropical Medicine and Hygiene, vol. 34, no. 6, p. 1069-1075.

NEAL, EG. and CHEESEMAN, C., 1996. Badgers. London: T. and A.D. Poyser.

NESBITT, WH., 1975. Ecology of a feral dog pack on a wild refuge. In FOX, MW. (Ed.). The wild canids. New York: Van Nostrand Reinhold, p 391-395.

OLIVEIRA, VB., LINARES, AM., CÔRREIA, GLC. and CHIARELLO, AG., 2008. Predation on the capuchin monkey Cebus nigritus (Primate: Cebidae) by domestic dog Canis lupus familiaris (Carnivora: Canidae), in the Parque Estadual Serra do Brigadeiro. Revista Brasileira de Zoologia, vol. 25, no. 2, p. 276-278.

ORTEGA-PACHECO, A., RODRIGUEZ-BUENFIL, JC., BOLIOGONZALES, ME., SAURI-ARCEO, CH., JIMÉNEZ-COELHO, M. and FORSBERG, CL., 2007. A survey of dog populations in urban and rural areas of Yucatan, Mexico. Anthrozoos, vol. 20. no. 3, p 261-274.

PARDINI, R., DITT, EH., CULLEN, L., BASSI, C. and RUDRAN, R., 2003. Rapid survey on medium and large terrestrial mammals. In CULLEN, L., RUDRAN, R. and PADUA, CV. (Orgs.). Study methods in conservation biology and wildlife management. Curitiba: Editora UFPR, p. 181-201.

PASSAMANI, M. and RIBEIRO, D., 2009. Small mammals in a fragment and adjacent matrix in southeaster Brazil. Brazilian Journal of Biology, vol. 69, no. 2, p. 305-309.

R DEVELOPMENT CORE TEAM, 2006. $R$ : A language and environment for statistical computing. Vienna, Austria: $\mathrm{R}$ Foundation for Statistical Computing, Available from: <http:// www.R-project.org>.

REITHINGER, R., ESPINOZA, JC., LLANOS-CUENTAS, A. and DAVIES, CR., 2003. Domestic dos ownership: a risk factor for human infection with Leishmania (Viannia) species. Transactions of the Royal Society of Tropical Medicine and Hygiene, vol. 97, p. 141-145.

REVILLA, E., PALOMARES, F. and DELIBES, M., 2001. Edgecore effects and the effectiveness of traditional reserve conservation: Eurasian badgers in Doñana National Park. Conservation Biology, vol. 15 , p. $148-158$.

SRBEK-ARAUJO, AC. and CHIARELLO, AG., 2005. Is cameratrapping an efficient method for surveying mammals in Neotropical forests? A case study in south-eastern Brazil. Journal of Tropical Ecology, vol. 21, p. 121-125.

SRBEK-ARAUJO, AC. and CHIARELLO, AG., 2008. Domestic dogs in Atlantic forest preserves of south-eastern Brazil: a cameratrapping study on patterns of entrance and site occupancy rates. Brazilian Journal of Biology, vol. 68, no. 4, p. 771-779.

THOMSON, PC., ROSE, K. and KOK, NE., 1992. The behavioral ecology of dingos in north-western Australia. 5. Populationdynamics and variation in the social system. Wildlife Research, vol. 19 , no. 5 , p. 65-584.

VERNES, K., DENNIS, A. and WINTER, J., 2001. Mammalian diet and broad hunting strategy of the dingo (Canis familiaris dingo) in the wet tropical rain forests of northeastern Australia. Biotropica, vol. 33, no. 2, p. 339-345.

VIANA, VM., TABANEZ, AAJ. and BATISTA, JLF., 1997. Dynamics and Restoration of Forest Fragments in the Brazilian Atlantic Moist Forest. In LAURANCE, WF. and BIERREGAARD, RO. (Eds.). Tropical Forest Remnants: ecology, management, $e$ conservation of fragmented communities. Chicago: The University of Chicago Press, p. 151-165.

WANG, Y., HE, T., WEN, X., LI, T., WAILI, TT., ZHANG, W., ZHOU, H., ZHENG, H., WEN, H., DAVAADORJ, N., GAMBOLT, L., MUKHAR, T., ROGAN, MT. and CRAIG, PS., 2005. Human cystic echinococcosis in two Mongolian communities in Hobukesar (China) and Bulgan (Mongolia). Transactions of the Royal Society of Tropical Medicine and Hygiene, vol. 99, p. 692-698.

WHITEMAN, CW., MATUSHIMA, ER., CONFALONIERI, UEC., PALHA, MDC., SILVA, ASL. and MONTEIRO, VC., 2007. Human and domestic animal populations as a potential threat to wild carnivore conservation in a fragmented landscape from the Eastern Brazilian Amazon. Biological Conservation, vol. 138, p. 290-296.

YANOSKI, AA. and MERCOLLI, C., 1990. The use of wetland areas by nocturnal mammals, with emphasis to Cerdocyon thous LINNEUS, 1977 and Procyon cancrivoros CUVIER, 1978. Spheniscos, vol. 8, p. 11-20. 